\title{
Impact of portal technologies on EIS implementations in organizations in KwaZulu-Natal
}

\section{Udo Averweg}

Information Services Department, eThekwini Municipality, Durban, South Africa

Durban Institute of Technology, South Africa

averwegu@durban.gov.za

\section{Don Petkov}

Eastern Connecticut State University, United States of America petkovD@easternct.edu

\section{Geoff Erwin}

Faculty of Business Informatics, Cape Technikon, Cape Town, South Africa

erwing@ctech.ac.za

\section{Henri Moolman}

School of Mathematical Sciences, University of Natal, Durban, South Africa moolmanh@nu.ac.za

\section{Contents}

- Introduction

- Background and goal of the research

- Research method and data gathering

- Results and discussions

- Concluding remarks

- $\underline{\text { References }}$

\section{Introduction}

Portals enable users to access multiple applications via a single point of entry with a browser (PricewaterhouseCoopers 2002). Leveraging knowledge - both internal and external - is the key to using a portal as a centralized database of best practices that can be applied across all departments and all lines of business within an organization (Zimmerman 2003). Portal technologies integrate information, content and enterprise applications. Portals 'aim to serve particular communities, including various business groups' (Deise, Nowikow King and Wright 2000). A portal aims to establish a community of users with a common interest or need. 
Portals include horizontal applications such as search, classification, content management, business intelligence (BI), Executive information systems (EIS) and a myriad of other technologies. Portals not only pull these together but are also absorbing much of the functionality from these complementary technologies (Drakos 2003). When paired with other technologies such as content management, collaboration and BI, portals can improve business processes and boost efficiency within and across organizations (Zimmerman 2003).

Gartner defines a portal as 'access to and interaction with relevant information assets (information/content, applications and business processes), knowledge assets and human assets, by select target audiences, delivered in a highly personalized manner' (Drakos 2003). Organizations without a portal framework will be at a competitive disadvantage (Meta Group 2003). Drakos (2003) suggests that a significant convergence is occurring with portals in the centre. Most organizations are being forced to revisit their enterprise-wide Web integration strategies (Hazra 2002). Enterprise Information Portals are becoming the primary way in which organizations organize and disseminate knowledge (PricewaterhouseCoopers 2001).

EIS grew out of the development of IS to be used directly by executives and used to augment the supply of information by subordinates (Srivihok 1998). The development of BI is closely related to EIS technology. For the purposes of this article, EIS is defined as 'a computerized system that provides executives with easy access to internal and external information that is relevant to their critical success factors' (Watson, Houdeshel and Rainer 1997). EIS are an important element of the information architecture of an organization. IS to support senior executives have been available for well over a decade (Poon and Wagner 2001). Different EIS software tools and/or enterprise resource planning (ERP) software with EIS features exist. EIS is a technology that is continually emerging in response to managers' specific decision-making needs (Turban, McLean and Wetherbe 1999). Turban (2001) suggests that EIS capabilities are being 'embedded in BI'. All major EIS and information product vendors now offer Web versions of the tools designed to function with Web servers and browsers (PricewaterhouseCoopers 2002).

Web-based technologies are causing a revisit to existing IT implementation models, including EIS (Averweg,Cumming and Petkov 2003). Web-based tools 'are very much suited' to executives' key activities of communicating and informing (Pijpers 2001). With the emergence of global IT, existing paradigms are being altered, which are spawning new considerations for successful IT implementation (Averweg and Erwin 2000). Challenges exist in building enterprise portals as a new principle of software engineering (Hazra 2002). Yahoo! is an example of a general portal. Yahoo! enables the user to maintain a measure of mastery over a vast amount of information (PricewaterhouseCoopers 2001). The Web is 'a perfect medium' for deploying decision support and EIS capabilities on a global basis (Turban et al. 1999).

\section{Background and goal of the research}

During the past two decades, advances in computer technologies, combined with telecommunication technologies, have led to the development of the Internet and its most popular application, the World Wide Web ('the Web') (Khosrowpour 2000). A new set of challenges has arisen as organizations integrate IT into all functions and activities of the modern organization (Khosrowpour and Liebowitz 1997).

As the usage of IT increases, Web-enabled information technologies can provide the means for greater access to information from disparate computer applications and other information resources (Eder 2000). These Web-based technologies include: intranet, Internet, extranet, e- 
commerce business-to-business (B2B), e-commerce business-to-consumer (B2C), wireless application protocol (WAP) and other mobile and portal technologies. The portal has become the mostdesired user interface in Global 2000 enterprises (Drakos 2003). There exists a high degree of similarity between the characteristics of a 'good EIS' and Web-based technologies (Tang, Lee and Yen 1997).

Recent studies have investigated factors affecting the use of the Internet or Web (Anandarajan, Simms and Igbaria 2000; Moon and Kim 2001). The theoretical basis adopted in all these studies is the popular technology acceptance model (TAM) (Davis 1989; Davis, Bogozzi and Warshaw 1989) or its extensions. TAM is a well respected model of IT adoption and use (Al-Gahtani 2001). It is often used to gain a better understanding of the adoption and use of IS (Chen 2000). TAM is one of the most influential research models in studies of the determinants of IS acceptance (Davis 1989; Davis et al. 1989; Mathieson 1991).

User acceptance of IT has been a primary focus in IT implementation research (Al-Gahtani 2001). Researchers in the field rely on the theories of innovation diffusion to study implementation problems. Davis' (Davis 1989; Davis et al. 1989) TAM is based on the diffusion of innovation model.

Computer or IS usage has been identified as the key indicator of the adoption of IT by organizations (Suradi 2001). Igbaria and Tan (1997) report that system usage is an important variable in IT acceptance since it appears to be a good surrogate measure for the effective deployment of IS resources in organizations. Lu and Gustafson (1994) report that people use computers because they believe that computers will increase their problem-solving performance (usefulness) and they are relatively effort free to use (ease of use). From the available literature, there is little evidence to suggest that the impact of Web-based technologies on EIS implementations has previously been investigated. This creates a fertile platform for conducting such research.

The main goal of this research is to investigate and quantify the areas of impact (if any) of portal technologies on EIS usage in well-established organizations in the province of KwaZulu-Natal. It is acknowledged that some organizations may have implemented more than one EIS. In those cases and for this study, only the latest EIS implementation was used in the authors' survey.

The technology for EIS is evolving rapidly and future systems are likely to be different (Sprague and Watson 1996). EIS is now clearly in a state of flux. As Turban (2001) notes, 'EIS is going through a major change'. There is therefore both scope and need for research in the particular area of EIS being impacted by portal technologies as executives need systems that provide access to diverse types of information. As with any other IT investment, the use for a portal must be well-understood (Drakos 2003). Emerging (Web based) technologies can redefine the utility, desirability and economic viability of EIS technology (Volonino, Watson and Robinson 1995).

With the absence of any research efforts on the impact of portal technologies on EIS usage in South Africa, this research begins to fill the gap with a study of selected organizations in KwaZulu-Natal which have implemented EIS.

\section{Research method and data gathering}

The survey instrument developed by the first author was based on previous instruments used 
in published research reports (Davis, 1989; Davis et al. 1989; Averweg 2002). The questionnaire consisted of six parts. Section 1 (organization's demographics) and Section 2 (attributes of the organization's EIS) were extracted and translated from the Roldán (2000) EIS questionnaire. Section 3 was drawn from the established Davis (1989) questionnaire. Following the work of Davis (1989), Section 4 (current Web-based technologies) and Section 5 (future Web based technologies) each contained seven-point Likert scale statements [anchored with (1) Not at all and (7) Extensively] dealing with how an interviewee perceived the impact of specific Web-based technologies on his or her organization's EIS implementation. The Web based technologies were (a) intranet; (b) Internet; (c) extranet; (d) e-commerce: business-to-business (B2B); (e) e-commerce: business-to-consumer (B2C); (f) wireless application protocol (WAP) and other mobile technologies; and (g) any other Web-based technologies (e.g. portal technologies). Section 6 contains an open-ended question allowing an interviewee to furnish general comments regarding the EIS implementation in his or her organization. The questionnaire was administered during a semi-structured interview process. Pooling data across different technologies was consistent with prior research in user acceptance (Davis 1989; Davis et al. 1989; Venkatesh and Morris 2000).

The sample was selected using the unbiased 'snowball' sampling technique. Cooper and Emory (1995) state that this technique has found a niche in applications where respondents are difficult to identify and are best located through referral networks. A formal extensive interview schedule was compiled and used for the semi-structured interviews. Interviews were conducted during May and June 2002 at the interviewee’s organization.

There are six major metropolitan councils in South Africa. eThekwini Municipality Area (EMA) is the most populous municipality in South Africa (SA2002-2003, 2002). EMA's geographic area size is $2300 \mathrm{~km}^{2}$ with a population of 3026974 (eThekwini Municipal Area Development Profile, 2002). The authors' survey of organizations in KwaZulu-Natal that have implemented EIS was confined to organizations in the EMA.

Some studies suggest that EIS should not only be accessed by executive users (Volonino et al. 1995; Rai and Bajwa 1997). Salmeron (2001) notes EIS as the technology for information delivery for all business end-users. Kennedy (1995) and Messina and Sanjay (1995) report that EIS have spread throughout organizations. Portals can excel at combining transactional, informational and collaborative elements, including emerging Web services (Meta Group 2003). The non-executive users or data providers include personnel from functional areas that include accountancy, marketing services, risk analysis and tariff engineering. It is evident that EIS requires continuous input from three different stakeholder groups (known as constituencies):

- EIS executives/business end-users

- EIS providers (i.e. persons responsible for developing and maintaining the EIS)

- EIS vendors or consultants.

All constituencies were surveyed in the authors' data sampling.

A field study of 31 different organizations in the EMA that had successfully implemented EIS was conducted. Each semi-structured interview was conducted by the first author. An activity sector list of organizations surveyed by the authors is reflected in Table 1 .

Table 1 Activity sector list of organizations surveyed that have implemented EIS 


\begin{tabular}{|l|l|} 
& total sample surveyed (N = 31) \\
\hline Agriculture & $1(3,2 \%)$ \\
\hline Catering & $1(3,2 \%)$ \\
\hline Construction and automotive & $1(3,2 \%)$ \\
\hline Education & $1(3,2 \%)$ \\
\hline Electrical power distribution & $1(3,2 \%)$ \\
\hline Financial services & $6(19,5 \%)$ \\
\hline Food processing & $1(3,2 \%)$ \\
\hline Information technology services & $2(6,5 \%)$ \\
\hline Manufacturing & $7(22,6 \%)$ \\
\hline Medical scheme administrators & $1(3,2 \%)$ \\
\hline Public administration & $1(3,2 \%)$ \\
\hline Public transportation & $1(3,2 \%)$ \\
\hline Publishing & $1(3,2 \%)$ \\
\hline Retail & $2(6,5 \%)$ \\
\hline Software development & $1(3,2 \%)$ \\
\hline Warehousing and distribution & $2(6,5 \%)$ \\
\hline Water distribution & $1(3,2 \%)$ \\
\hline Total & $31(100,0 \%)$ \\
\hline &
\end{tabular}

\section{Results and discussions}

Twenty-seven (90\%) of organizations surveyed were large enterprises in the eThekwini Municipality region. One organization surveyed had an annual 'sales for the year exceeding R12 bn' (Butcher 2002).

The three EIS constituencies, number of surveyed interviewees and associated percentages per constituency are reflected in Table 2.

Table 2 EIS constituencies and number of interviewees surveyed per constituency

\begin{tabular}{|l|l|}
\hline Stakeholder groups (constituencies) & $\begin{array}{l}\text { Number of interviewees surveyed and } \\
\text { associated percentage of total sample }\end{array}$ \\
\hline EIS executives/business end-users & $20(64,5 \%)$ \\
\hline EIS providers & $7(22,6 \%)$ \\
\hline EIS vendors or consultants & $4(12,9 \%)$ \\
\hline Sample size & $31(100 \%)$ \\
\hline
\end{tabular}

The frequency of EIS usage reported by the respondents in the organizations surveyed is reflected in Table 3. Frequent (several times per day) and regular use of the EIS were reported by a total of 25 (80,6\%) respondents. An EIS has the effect of multiplying the frequency of use (Palvia, Kumar and Hendon 1996).

Table 3 Frequency of EIS usage reported by respondents and associated percentages 


\begin{tabular}{|l|l|} 
Frequency of EIS use in organization & $\begin{array}{l}\text { use in organizations as reported by } \\
\text { respondents in total sample surveyed } \\
(\mathbf{N}=\mathbf{3 1})\end{array}$ \\
\hline Very rarely or not at all & $1(3,2 \%)$ \\
\hline Rarely (a few times per month) & $1(3,2 \%)$ \\
\hline Occasionally (a few times per week) & $1(3,2 \%)$ \\
\hline Sometimes (about once per week) & $1(3,2 \%)$ \\
\hline Fairly regularly (several times per week) & $4(12,9 \%)$ \\
\hline Regularly (once a day) & $12(38,7 \%)$ \\
\hline Frequently (several times per day) & $13(41,9 \%)$ \\
\hline
\end{tabular}

Table 4 reflects data of the different available commercially purchased EIS software tools and/or ERP software with EIS features used by the respondents in the organizations surveyed. Some respondents surveyed reported using more than one EIS software tool and/or ERP software with EIS features. In such cases, all reported software is included in Table 4. Drakos (2003) reports that the portalization of vertical applications such as ERP, customer relationship management (CRM) and supply chain management (SCM) is driving multiple vertical portals into single enterprises.

Table 4 Distribution of market among vendors of EIS tools according to responses

\begin{tabular}{|l|l|}
\hline $\begin{array}{l}\text { Name of commercially purchased EIS } \\
\text { software tools and/or ERP software } \\
\text { with EIS features }\end{array}$ & $\begin{array}{l}\text { Tally and associated percentage of } \\
\text { commercially purchased EIS software } \\
\text { tools and/or ERP software with EIS } \\
\text { features as reported by respondents in } \\
\text { total sample surveyed (N = 30) }\end{array}$ \\
\hline Business Objects & $2(6,7 \%)$ \\
\hline Cognos & $18(60,0 \%)$ \\
\hline Crystal Enterprise & $1(3,3 \%)$ \\
\hline Holos & $1(3,3 \%)$ \\
\hline Hyperion & $3(10,0 \%)$ \\
\hline JDEdwards BI & $4(13,3 \%)$ \\
\hline Lotus Notes & $3(10,0 \%)$ \\
\hline Oracle & $4(13,3 \%)$ \\
\hline Pilot & $2(6,7 \%)$ \\
\hline ProClarity & $1(3,3 \%)$ \\
\hline SAP/EIS & $1(3,3 \%)$ \\
\hline MIMMS & $1(3,3 \%)$ \\
\hline MISYS & $1(3,3 \%)$ \\
\hline BI Query & $1(3,3 \%)$ \\
\hline
\end{tabular}

A summary of data obtained of the degree to which specific Web-based technologies impacted the respondents' EIS implementation in the organizations surveyed, is reflected in Table 5.

Table 5 Tally and associated percentage of the degree to which specific Web-based technologies impacted respondent's EIS implementation 


\begin{tabular}{|l|l|l|l|l|l|l|l|}
\hline \multicolumn{7}{|l|}{ respondents' EIS implementation (N = 31) } \\
\hline $\begin{array}{l}\text { Web-based } \\
\text { technology }\end{array}$ & $\begin{array}{l}\text { Not at } \\
\text { all }\end{array}$ & $\begin{array}{l}\text { Very } \\
\text { little }\end{array}$ & $\begin{array}{l}\text { Somewhat } \\
\text { little }\end{array}$ & Uncertain & $\begin{array}{l}\text { Somewhat } \\
\text { much }\end{array}$ & $\begin{array}{l}\text { Very } \\
\text { much }\end{array}$ & Extensively \\
\hline Intranet & $\begin{array}{l}17 \\
(54,8 \%)\end{array}$ & $\begin{array}{l}2 \\
(6,5 \%)\end{array}$ & $2(6,5 \%)$ & $0(0,0 \%)$ & $3(9,7 \%)$ & $\begin{array}{l}4 \\
(12,9 \%)\end{array}$ & $3(9,6 \%)$ \\
\hline Internet & $\begin{array}{l}21 \\
(67,7 \%)\end{array}$ & $\begin{array}{l}1 \\
(3,2 \%)\end{array}$ & $1(3,2 \%)$ & $0(0,0 \%)$ & $2(6,5 \%)$ & $\begin{array}{l}3 \\
(9,7 \%)\end{array}$ & $3(9,7 \%)$ \\
\hline Extranet & $\begin{array}{l}24 \\
(77,4 \%)\end{array}$ & $\begin{array}{l}1 \\
(3,2 \%)\end{array}$ & $2(6,5 \%)$ & $1(3,2 \%)$ & $1(3,2 \%)$ & $\begin{array}{l}2 \\
(6,5 \%)\end{array}$ & $0(0,0 \%)$ \\
\hline $\begin{array}{l}\text { e- } \\
\text { commerce: } \\
\text { B2B }\end{array}$ & $\begin{array}{l}28 \\
(90,4 \%)\end{array}$ & $\begin{array}{l}1 \\
(3,2 \%)\end{array}$ & $0(0,0 \%)$ & $0(0,0 \%)$ & $0(0,0 \%)$ & $\begin{array}{l}1 \\
(3,2 \%)\end{array}$ & $1(3,2 \%)$ \\
\hline $\begin{array}{l}\text { e- } \\
\text { commerce: } \\
\text { B2C }\end{array}$ & $\begin{array}{l}26 \\
(83,9 \%)\end{array}$ & $\begin{array}{l}1 \\
(3,2 \%)\end{array}$ & $1(3,2 \%)$ & $0(0,0 \%)$ & $2(6,5 \%)$ & $\begin{array}{l}0 \\
(0,0 \%)\end{array}$ & $1(3,2 \%)$ \\
\hline $\begin{array}{l}\text { WAP and } \\
\text { other } \\
\text { mobile } \\
\text { technologies }\end{array}$ & $\begin{array}{l}29 \\
(93,6 \%)\end{array}$ & $\begin{array}{l}1 \\
(3,2 \%)\end{array}$ & $0(0,0 \%)$ & $0(0,0 \%)$ & $0(0,0 \%)$ & $\begin{array}{l}0 \\
(0,0 \%)\end{array}$ & $1(3,2 \%)$ \\
\hline $\begin{array}{l}\text { Portal } \\
\text { technologies }\end{array}$ & $\begin{array}{l}26 \\
(83,8 \%)\end{array}$ & $\begin{array}{l}0 \\
(0,0 \%)\end{array}$ & $0(0,0 \%)$ & $0(0,0 \%)$ & $2(6,5 \%)$ & $\begin{array}{l}2 \\
(6,5 \%)\end{array}$ & $1(3,2 \%)$ \\
\hline
\end{tabular}

Table 5 shows that only seven (22,5\%) of the organizations surveyed reported that the Intranet significantly impacted their EIS implementation. The level of impact by the Internet on EIS implementation was slightly lower with six $(19,4 \%)$ of the organizations surveyed reporting that the Internet had significantly impacted their EIS implementation. While 24 $(77,4 \%)$ of the organizations surveyed reported that the extranet had no impact on their organization's EIS implementation, the balance of the data sample $(22,6 \%)$ reported different degrees of impact. An earlier study by Averweg, Petkov, Erwin and Moolman (2003) reports similar findings.

The results show that the vast majority $(90,4 \%)$ of respondents reported that e-commerce: B2B had not impacted EIS implementation in organizations surveyed. A slightly lower result $(83,9 \%)$ was reported for e-commerce: B2C. One possible explanation for the e-commerce B2B and B2C low impact levels is that the software development tools are still evolving and changing rapidly.

WAP and other mobile technologies had no (93,6\%) or very little (3,2\%) impact on EIS implementations. Of the seven Web-based technologies given in Table 5, WAP and other mobile technologies had the least impact (combining 'Somewhat much', 'Very much' and 'Extensively') on EIS implementation in organizations surveyed. Only one respondent $(3,2 \%)$ reported that WAP and other technologies had extensively impacted the EIS implementation in her organization. A possible explanation for this result is that the EIS consultant was technically proficient in WAP technologies. The potential benefit of mobile access to portals are numerous and self-evident. However, as PricewaterhouseCoopers (2002) note, organizations must first establish the benefits of mobile access to its portal and assess the value of providing those benefits via mobile access to the organization.

Three interviewees reported that their organizations' EIS implementations were significantly impacted ('Very much' and 'Extensively') by portal technologies (Table 5). This is noteworthy as the portal technology impact on EIS implementations $(9,7 \%)$ was higher than the impact of the extranet (6,5\%), e-commerce: B2B (6,4\%), e-commerce: B2C (6,4\%) and 
WAP and other technologies (3,2\%). This means that after the intranet and Internet, portal technologies had the third highest impact on EIS implementations in organizations surveyed. Combining the results ('Somewhat much', 'Very much' and 'Extensively') for each of the seven Web-based technologies, Table 6 gives a descending ranking order of the levels of impact on EIS implementations. This information is particularly useful for IT practitioners planning future EIS implementations.

Table 6 Descending rank order of impact levels of Web based technologies on EIS implementation

\begin{tabular}{|l|l|l|}
\hline Rank & Web-based technology & $\begin{array}{l}\text { Tally and level of impact on EIS } \\
\text { implementations }\end{array}$ \\
\hline 1 & Intranet & $10(32,2 \%)$ \\
\hline 2 & Internet & $8(25,9 \%)$ \\
\hline 3 & Portal technologies & $5(16,2 \%)$ \\
\hline 4 & Extranet & $3(9,7 \%)$ \\
\hline 5 & e-commerce: B2C & $3(9,7 \%)$ \\
\hline 6 & e-commerce: B2B & $2(6,4 \%)$ \\
\hline 7 & WAP and other mobile technologies & $1(3,2 \%)$ \\
\hline
\end{tabular}

Meta Group expects B2B usage (encompassing partner and supplier portals) to expand by 35\% by 2004 and 50\% by 2006 (Meta Group 2003). The need for a portal usually becomes evident when an intranet (or sometimes an extranet or Internet site) accumulates more information than can be presented in a static manner. Enterprise portal is a new approach in intranet-based applications. It is often referred to as next generation intranet (Bajgoric 2000). Bajgoric notes that it goes a step further in the 'Webification' of applications and integration of corporate data.

Several 'portal-based' products, particularly from the BI area, exist. The Hummingbird Enterprise Information portal ${ }^{\circledR}$ (http://www.hummingbird.com) is an example of an integrated enterprise-wide portal solution. It provides organizations with a Web-based interface to unstructured and structured data sources and applications. The market for portal products will continue to coalesce during the next several years (Meta Group 2003). Some markets (e.g. Web content management) may completely merge with the portal market by 2004 (Drakos 2003). Access to applications is a critical feature that distinguishes the current generation of enterprise portals from their predecessors (PricewaterhouseCoopers 2002).

BI portal is a new software product based on the Web concept of a portal site that lets organizations deliver information from a variety of sources to end-users (Bajgoric 2000). Bajgoric (2000) reports that an enterprise information portal describes a system that can be used to combine an organization's internal data with external information, which provides a powerful decision support capability. WebIntelligence ${ }^{\circledR}$ from Business Objects (http://www.businessobjects.com) includes a BI portal that gives users a single Web entry point for both WebIntelligence ${ }^{\circledR}$ and BusinessObjects ${ }^{\circledR}$, the organization's client-server reporting and OLAP system. Brio.Portal ${ }^{\circledR}$ from Brio Technology is another example of integrated BI software capable of retrieving, analysing and reporting information over the Internet. The role of portals is to ferry information to the users. Developers must be aware of emerging trends in the portal market to create systems that will be able to incorporate the latest technological developments and new methods of information delivery and presentation (Meta Group 2003). Personalized technologies are becoming part of the portal environment (Zimmerman 2003). 


\section{Concluding remarks}

The findings of this survey show that while EIS have a significant role in organizations in the EMA, their technological base is not affected considerably by the latest innovations of Webbased technologies. This requires further investigation as to whether it is a signal for the fact that IT in South Africa is not transforming fast enough to adopt portal technologies.

The authors contend that portal technologies will become part of the organizational structure fabric and change the way infrastructure is viewed by the IT organization. Two trends will drive organizations to accept portals as business-critical: the ability to (a) deliver the availability and security required to support mission-critical functions; and (b) meet the needs of users outside the organization's employees. Organizations will need to take the database knowledge in their organizations and open it to business partners and suppliers in an effort to try and build a community. There must be a desire to make these commitments worthwhile and draw users back to the portals.

\section{References}

Al-Gahtani, S.S. 2001. The applicability of the technology acceptance model outside North America: An Empirical Test in the Arab World. Proceedings of the BITWorld 2001 Conference, American University in Cairo, 4-6 June. Cairo: AUC.

Anandarajan, M., Simmers, C. and Igbaria, M. 2000. An exploratory investigation of the antecedents and impact of Internet usage: An individual perspective. Behavior \& Information Technology 19(1):69-85.

Averweg, U.R. 2002. Executive information systems Usage: The impact of Web-based technologies. Unpublished Master of Science dissertation. Pietermaritzburg: University of Natal.

Averweg, U.R.F. and Erwin, G.J. 2000. Executive information systems in South Africa: a research synthesis for the future. Proceedings of the South African Institute of Computer Scientists and Information Technologists Conference (SAICSIT-2000), 13 November. Cape Town: SAICSIT.

Averweg, U., Cumming, G. and Petkov, D. 2003. Development of an executive information system in South Africa: some exploratory findings. Proceedings of a Conference on Group Decision and Negotiation (GDN2003) held within the 5th EURO/INFORMS Joint International Meeting, 7-10 July. Istanbul: GDN.

Averweg, U., Petkov, D., Erwin, G. and Moolman, H. 2003. The impact of Web-based technologies on EIS in South Africa: some exploratory findings. Proceedings of the Institute for Operations Research and the Management Sciences (INFORMS) Conference, 19-22 October. Atlanta: INFORMS.

Bajgoric, H. 2000. Web-based information access for agile management. International Journal of Agile Management Systems 2(2):121-129.

Butcher, C. (ed) 2002. SPAR: Striving for Excellence. Professional Management Review, May:18-20. 
Chen, L. 2000. Consumer acceptance of virtual stores: A theoretical model and critical success factors for virtual stores. Unpublished PhD dissertation. Mempis: University of Memphis.

Cooper, D.R. and Emory, C.W. 1995. Business research methods. New York: Richard D. Irwin.

Davis, F.D. 1989. Perceived usefulness, perceived ease of use, and user acceptance of information technology. MIS Quarterly 3(3):319-342.

Davis, F.D., Bagozzi, R.P. and Warshaw, P.R. 1989. User acceptance of computer technology: a comparison of two theoretical models. Management Science 35(8):982-1003.

Deise, M.V., Nowikow, C., King, P. and Wright, A. 2000. Executive's guide to e-business: from tactics to strategy. New York: John Wiley.

Drakos, N. 2003. Portalising your enterprise. Gartner Symposium ITXPO2003, 46 August. Cape Town: Gartner.

Eder, L.B. 2000. Managing healthcare information systems with Web-enabled technologies. Hershey: Idea Group Publishing.

eThekwini Municipal Area Development Profile, 2002. Changing Durban for good. Durban: eThekwini.

Hazra, T.K. 2002. Building enterprise portals: principles to practice. Proceedings of the 24th International Conference on Software Engineering, 19-25 May. Orlando, Florida: International Conference on Software Engineering.

Igbaria, M. and Tan, M. 1997. The consequences of information technology acceptance on subsequent individual performance. Information \& Management 32(3):113-121.

Kennedy, D.H. 1995. Everybody’s information systems? Management Accounting London 73(5):4.

Khosrowpour, M. 2000. Web-Enabled Technologies Assessment and Management: Critical Issues. In: Managing Web enabled technologies in organizations: a global perspective. Hershey: Idea Group Publishing.

Khosrowpour, M. and Liebowitz, J. 1997. Cases on information technology in modern organizations. Hershey: Idea Group Publishing.

Lu, H.P. and Gustafson, D.H. 1994. An empirical study of perceived usefulness and perceived ease of use on computerized support system use over time. International Journal of Information Management 14(5):317 329.

Mathieson, K. 1991. Predicting user intentions: Comparing the technology acceptance model with the theory of planned behavior. Information Systems Research 2(3):173-191.

Messina, F.M. and Sanjay, S. 1995. Executive information systems: Not just for executives anymore! Management Accounting 77(1):60 63.

Meta Group, 2003. Best practises in enterprise portal development. executive summary. London: Meta Group. 
Moon, J.W. and Kim, Y.G. 2001. Extending the TAM for a World Wide Web context. Information \& Management 38(4):217-230.

Palvia, P., Kumar, A., Kumar, N. and Hendon, R. 1996. Information requirements of a global EIS: An exploratory macro assessment. Decision Support Systems 16(2):169 179.

Pijpers, G.G.M. 2001. Understanding senior executives' use of information technology and the Internet. In: Managing Web usage in the workplace: a social, ethical and legal perspective. Hershey: Idea Group Publishing.

Poon, P. and Wagner, C. 2001. Critical success factors revisited: success and failure cases of information systems for senior executives. Decision Support Systems 30(4):393-418.

PricewaterhouseCoopers, 2001. Technology forecast: 2001-2003. Mobile Internet: unleashing the power of wireless. Los Angeles: PricewaterhouseCoopers.

PricewaterhouseCoopers, 2002. Technology forecast: 2002-2004. Volume 1: navigating the future of software. Los Angeles: PricewaterhouseCoopers.

Rai, A. and Bajwa, D. 1997. An empirical investigation into factors relating to the adoption of EIS: an analysis for collaboration and decision support. Decision Sciences 18(1):939 974.

Roldán J.L. 2000. Sistemas de información ejecutivos (EIS): Génesis, implantación y repercusiones organizativas. Unpublished thesis, Universidad de Sevilla, Spain.

SA2002-2003, 2002. South Africa at a glance. Craighall: Editors Inc.

Salmeron, J.L. 2001. EIS evolution in large Spanish businesses. Information \& Management 19:1-10.

Sprague, R.H., Jr. and Watson, H.J. 1996. Decision support for management. Upper Saddle River: Prentice-Hall.

Srivihok, A. 1998. Effective management of executive information systems implementations: A framework and a model of successful EIS implementation.

Unpublished PhD dissertation. Rockhampton, Australia: Central University.

Suradi, Z. 2001. Testing technology acceptance model (TAM) in Malaysian environment. BITWorld 2001 Conference Proceedings, 4-6 June. Cairo: American University in Cairo.

Tang, H., Lee, S. and Yen, D. 1997. An investigation on developing Web-based EIS. Journal of CIS 38(2):49-54.

Turban, E. 2001. California State University, Long Beach and City University of Hong Kong, USA, 7 October. Personal communication.

Turban, E., McLean, E. and Wetherbe, J. 1999. Information technology for management. New York: John Wiley.

Venkatesh, V. and Morris, M.G. 2000. Why don’t men ever stop to ask for directions? gender, social influence, and their role in technology acceptance and usage behavior. MIS Quarterly 24(1):115-139. 
Volonino, L., Watson, H.J. and Robinson, S. 1995. Using EIS to respond to dynamic business conditions. Decision Support Systems 14(2):105-116.

Watson, H.J., Houdeshel, G. and Rainer, R.K. Jr. 1997. Building executive information systems and other decision support applications. New York: John Wiley.

Zimmerman, K.A. 2003. Portals: no longer a one-way street. KMWorld: Creating and Managing the Knowledge-Based Enterprise 12(8):13-15.

\section{Disclaimer}

Articles published in SAJIM are the opinions of the authors and do not necessarily reflect the opinion of the Editor, Board, Publisher, Webmaster or the Rand Afrikaans University. The user hereby waives any claim he/she/they may have or acquire against the publisher, its suppliers, licensees and sub licensees and indemnifies all said persons from any claims, lawsuits, proceedings, costs, special, incidental, consequential or indirect damages, including damages for loss of profits, loss of business or downtime arising out of or relating to the user's use of the Website. 
ISSN 1560-683X

Published by InterWord Communications for Department of Information Studies, Rand Afrikaans University 